\title{
Creativity and Its Relationship with Vocabulary Learning Strategy Use of EFL Students
}

\author{
Fatemeh Seddigh \\ English Department, Faculty of Paramedical Sciences \\ Shiraz University of Medical Sciences, Shiraz, Iran \\ Tel: 98-917-316-2855 E-mail: fseddigh.english@yahoo.com \\ Nasrin Shokrpour (Corresponding Author) \\ English Department, Faculty of Paramedical Sciences \\ Shiraz University of Medical Sciences, Shiraz, Iran \\ Tel: 98-917-316-2815 E-mail: shokrpourn@gmail.com
}

Received: Jan. 31, 2013 Accepted: March 1, 2013 Published: May 1, 2013

doi:10.5296/jse.v3i2.3199 URL: http://dx.doi.org/10.5296/jse.v3i2.3199

\begin{abstract}
The relationship between SLA and individual differences has been investigated by many scholars and examining the psychological variables, one of which is creativity, seems to be a trend. The number of studies on vocabulary learning strategies (VLS) is much more than the size of research on the relationship between psychological factors and such strategies. The present study takes a step toward the clarification of whether the psychological parameter of creativity plays any significant role in the use of VLS by EFL students. Therefore, this paper aims to explore the relationship between Iranian EFL students' creativity and their use of vocabulary learning strategies. Also, there is an attempt to find out if gender plays any role in this relationship. For measuring the creativity of a group of 101 medical students at Shiraz University of Medical Sciences (SUMS), the Torrance Test of Creative Thinking (Torrance, 1990) was conducted. Subsequently a VLS questionnaire (Jones, 2006) was given to the participants to identify their VLS employment. The results revealed that the participants possessed a high level of creativity but there was no significant difference in this regard according to gender. A significant correlation was found between creativity and the overall VLS use of female students, but not for males. However, the correlation observed between creativity and the overall VLS use of the participants was statistically significant in general.
\end{abstract}

Keywords: Creativity, Vocabulary learning strategies (VLS), relationship 


\section{Introduction}

During the last decades, many scholars (Altman,1980; Skehan,1989;Larsen- Freeman \& Long, 1991; Ellis, 1994; Segalowitze, 1997; Dörnyei, 2005 ) have studied the relationship between second language acquisition (SLA) and psychological variables, i.e. individual differences such as motivation, self-esteem, self- efficacy, and anxiety. In comparison, however, creativity has been a somehow neglected variable in the research on individual differences. To the best of our knowledge, this study is the first to examine creativity and its relationship with vocabulary learning strategies (VLS). A number of researchers (Barkoczi and Zetenyi, 1981; Cropley, 1972; Guliford, 1950; Harrington, Block and Block, 1983, all cited in Albert, 2006) believe that the underlying components of creativity are normally distributed in the population. In other words, creativity is ability or some abilities possessed by all people to some degree. Therefore, creativity which implicitly involves imagination, unconventionality, risk-taking, flexibility and creating new classifications and systematizations of knowledge (Sternberg, 1985) can be an important factor affecting language learning acquisition.

\subsection{Creativity}

The concept of creativity covers different but relevant phenomena such as "the creative performance or product, the creative person, the creative situation, the creative process, and the creative potential.”(Brown, 1989; Lubart; 1994; as cited in Albert and Kormos, 2011: 75). In the current investigation, we will focus on the potential aspect of creativity that is "the cognitive underpinnings of the creative working of the mind” (Albert and Kormos, 2011, 75).

Matsouka et al. (2003) believe that creativity is a multidimensional construct which can be measured as a creative style or a personality trait. Abutalebi and Costa (2008) define it as a unique ability of people and the undiscovered secret of the brain. According to Kim (2008), E. Paul Torrance is the 'father of creativity' because of his 60 years of research. In fact, his research is the framework for the area of creative education and creative thinning tests. Hadley (2003) emphasizes the importance of creative effect in second or foreign language learning and the use of language creatively. He believes that learners must learn to use language creatively to progress beyond the elementary phases.

Creativity which involves novelty should be a priority in communicative and task-based methods of teaching since in these methods learners need to use their imagination to perform the tasks. In this way, the learners become creative and produce better outputs leading to successful SLA. It might be even more important in a foreign language situation where the output is mainly produced in the classroom (Albert \& Kormos, 2011). This idea is supported by Otto (1998) who carried out a small-scale study in which communicative methods were employed to instruct Hungrian secondary school learners. The results showed significant positive correlations between the learners' creativity and their final English grades. To study the effect of creativity on language learning success, it is also worthwhile to investigate its relationship with language learning strategies which play a very remarkable role in language learning. So, the present study aims to examine the relationship between creativity and VLS, greatly influential in language learning. 


\subsection{Vocabulary Learning Strategies}

VLSs are a subcategory of language learning strategies particularly effective in language learning. "A vocabulary strategy is a special instructional tool and way of going about directly or explicitly as well as the independent word learning skills required to learn words independently." (Naveh et al., 2011, p.105). Another definition for VLS is proposed by Catalan (2003) "knowledge about the mechanisms (processes, strategies) used in order to learn vocabulary as well as steps or actions taken by students (a) to find out the meaning of unknown words, (b) to retain them in long-term memory, (c) to recall them at will, and (d) to use them in oral or written mode.” (p.56). VLSs are actually any techniques employed by learners in order to learn words more easily, quickly and independently. In fact, a number of researchers have emphasized the "learner's independence” in VLS. Gairns and Redman (1986, as cited in Kafipour et al, 2011) believe that learners should be more responsible for their own learning and they pay more attention to their individual needs. Nation (1990, 2001) maintains that the most effective way to learn vocabulary is learners' use of strategies independently of a teacher. Therefore, VLSs develop the 'autonomy' of the students by allowing self-directed involvement, helping them gain control of their learning (Oxford, 1990)

Different VLS taxonomies have been presented by researchers; however, there is not one suitable for all situations. Schmitt (2000) provided a list of VLS classified based on the following two purposes:1) strategies for discovering the meaning of a new word, and 2) strategies for consolidating a word when it has been encountered. The former consists of determination and social strategies and the latter includes social, memory, cognitive and metacognitive strategies. His taxonomy is based, in part, on Oxford's (1990) classification containing social, memory, cognitive and metacognive strategies. Both classifications are comprehensive and reliable. Schmitt's (2000) taxonomy is also very elaborate and extensive.

Jones (2006) adopted his VLS taxonomy from other linguists' classifications (Fan, 2003; Gu and Johnson, 1996: Nation, 2001; O’Malley and Chamot, 1990; Oxford, 1990; Schmitt, 2000). According to this taxonomy, as adopted in the current study, strategies are classified under eight parts as dictionary, guessing, study preferences, memory, autonomy, note-taking, selective attention and social strategies.

It has usually been found that more proficient learners employ more dictionary and guessing strategies (Fan, 2003, Gu \& Johnson, 1996). Study preferences refer to the way students prefer to study vocabulary, that is studying alone, with another learner or in a group. Memory strategies are used to recall the words such as keeping a record of new vocabularies or writing them several times or repeat them aloud. Autonomy is related to motivation. If a learner is motivated, he/she feels reasonability for his/her own learning. An autonomous learner makes opportunities outside the class to learn English, for example watching movies on TV in English. Note-taking strategies are a kind of cognitive strategies indicating what types of words are written down by the learners, e.g. common words, words of personal interest or words considered useful by learners. They also show what type of information about words is written down such as meaning, pronunciation, etc.. Selective attention is an example of 
metacongnitive strategies which involves planning, monitoring, evaluating and organizing one's own learning (Oxford 1995: Rubin, 1987). Social strategies are those chosen by the learners to interact with other learners or native speakers (Cohen and Dörnyei, 2002).

\subsection{Review of Literature}

Otto (1998), as mentioned before, conducted a study on the relationship between individual differences in learners' creativity and language learning success. The results indicated a possible direct relationship between language proficiency and creativity. In contrast, Albert (2006) failed to find significant correlations between creativity and proficiency of 41 advanced learners. In his study, creativity appeared to be unrelated to the general proficiency level. He suggested that there is a need to study the relationship between creativity and specific language tasks. Subsequently, Albert and Kormos (2011) carried out a study on creativity and narrative task performance. Their subjects were Hungarian secondary school students learning English. A standardized creativity test was employed to measure creativity and two versions of a narrative task were performed by the learners. It was found that the difference in creativity is responsible for specific differences in narrative task performance of the learners. Creativity is hypothesized as a multifaceted trait in this study since learners with high scores on different components of creativity performed the same task in various ways. Those who employed a large number of solutions for a creativity test were engaged in more talk. Therefore, they may create more opportunities to employ the language in a foreign language setting. Another group of learners with a higher level of originality spoke less and produced more complex stories. There was no significant relationship among creativity and complexity, accuracy and lexical variety. The results also showed that there is just a moderate relationship between creativity and learners' output in narrative tasks.

Yar Hamidi et al. (2008) focused on creativity in entrepreneurship education and attempted to find out whether learners' creative potentials have any relationship with their intention to enroll in entrepreneurship. They found a positive association between high scores on creativity and entrepreneurial intentions, suggesting that creative disposition should be paid attention in models of entrepreneurship intentions. The results show that exercises in creativity can be employed to increase the entrepreneurial intentions of learners. Hajilou et al (2012) studied the role of creativity in productive/receptive learning of vocabulary of 141 Iranian EFL learners majoring in English translation and literature. They found significant but not strong correlations between creativity and lexical reception and production. In other words, by enhancing the active and passive knowledge of the learners we cannot explicitly say that they have higher levels of creativity as well. However, there were high correlations between the students' active and passive vocabulary knowledge as a whole and at all levels. Regarding passive and active vocabularies at all levels, the former was always larger, but the difference between the two was more at lower word-frequency levels.

Unlike creativity, there is more research regarding VLS of Iranian students. Riazi (2005) conducted a study on the effect of EFL learners' L2 proficiency and age and their VLS use. The subjects were 213 language students with different levels of proficiency, between 13-60 years old. The results indicated that the two factors, age and proficiency, influence the use of 
VLS. Older students used more cognitive strategies but fewer social and contextual strategies. Moreover, it was found that students with higher proficiency employed more cognitive strategies than those with lower-proficiency. Akbari and Tahririan (2009) focused on VLS in an ESP context. Their subjects were 137 Iranian paramedical students enrolled in ESP1 course. After challenging the existing taxonomies of VLS, the researchers tried to modify and complete Schmitt's (1997) taxonomy. They emphasized the critical role of motivation and added a category for affective strategies to Schmitt's taxonomy. They also recommended some effective approaches for vocabulary teaching and learning in an ESP context.

Soodmand Afshar (2010) attempted to find the most and least frequently- used VLS by 328 Iranian EFL majors and the relationship between gender and general strategy use. The students were divided into two groups, good and poor, with regard to their academic records and their grades of a placement test. He found out that both good and poor learners usually employ some strategies most or least frequently although sometimes the place of the strategies in the tables changed. No statistically significant difference could be found in the average frequency of the overall strategy use of female and male subjects. Fahim and Kamijani (2010) studied the relationship between critical thinking ability, vocabulary knowledge and VLS in L2. The participants were 70 intermediate Iranian EFL learners majoring in English literature, translation and teaching. The results showed a positive and significant correlation between their critical thinking ability and their vocabulary knowledge on one hand and their use of VLS on the other hand. The learners' L2 vocabulary knowledge correlated significantly and positively with determination, memorization, cognitive and metacognitive strategies but not with social strategies.

A similar study on vocabulary levels and VLS of Iranian students was conducted by Kafipour et al (2011). They found that Iranian EFL learners should be trained to use more VLS. Moreover, they noticed that memory strategies and cognitive ones were the most the and least frequently used strategies by these earners, respectively. A significant relationship was found between all VLSs and overall vocabulary level of Iranian undergraduate students.

Naveh et al. (2011) investigated the relationship between VLS and extroversion and reading comprehension of Iranian EFL undergraduate students. The results showed that only determination strategy didn't have any correlation with extroversion and reading comprehension. The other strategies, i.e. social, cognitive, memory and metacognitive and overall strategy use, correlated with either reading comprehension or extroversion tendency or both of them. Social strategy, unlike other strategies, showed a correlation with both extroversion and reading comprehension. Therefore, extroverted learners employed more social strategies and consequently had higher scores in reading comprehension. Unlike cognitive strategy, the other strategies and overall strategy use showed a stronger correlation with extroversion. Another study on the relationship between VLS and psychological variables, in this case self-efficacy beliefs, was performed by Heidari et al. (2012). They concluded that highly self-efficacious learners significantly employ more VLS than those who are less self-efficacious. Memory strategy was the most frequently used strategy and social affective strategies were the least frequently used ones. Seddigh and Shokrpur (2012) explored the use of VLS by Iranian medical students and noticed that female students used 
more VLSs than male ones and the difference was especially noticeable and significant in the case of guessing and note-taking strategies. Their results indicated that guessing and dictionary strategies had the highest frequency usage, while social and study preferences represented the lowest frequency use.

\subsection{Objectives of the Study}

The aim of the present study is to investigate the relationship between creativity and the use of VLS among medical students at Shiraz University of Medical Sciences (SUMS) in Iran where English is taught as a foreign language. There is an attempt in this study to find answers to the following research questions:

1. At what level of creativity are medical students at SUMS?

2. Is there any significant difference between creativity of male and female students?

3. Is there any significant relationship between creativity and VLS use of these students?

4. If such a relationship exits, is there any difference in this regard according to gender?

\subsection{Significance of the Study}

The relationship between psychological variables and second language acquisition has been emphasized during the last decades. The present study aims to find out if learner's creativity affects his/her use of VLS. If there is such a relationship, then EFL teachers, curriculum designers and even parents should develop creativity of their students and children to help them employ more VLS and subsequently learn a foreign language better.

\section{Methodology}

\subsection{Participants}

101 medical students including 53 males and 48 females at SUMS participated in this study. They were second or third year medical students, between 19-22 years old. They had studied English for 7 years in junior high school and high school and had passed at least two English courses at university before the time of data gathering. They were enrolled in ESP course at the time of data collection.

\subsection{Instruments}

Two instruments were utilized in this research. The first one was the Persian version of the Torrance Test of Creative Thinking (TTCT) (Torrance, 1990) which was administered to measure the creativity levels of the participants. It consists of 60 multiple choice questions and the choices include different hypothetical situations. The second instrument was the VLS questionnaire employed by Jones (2006) consisting of eight sections with a total number of 41 items about the learners' approach to vocabulary learning. The selection of VLS was measured by a 5-point Likert-style frequency scale based on Oxford (1990).

\subsection{Procedure}

Data collection which was done in the ESP classes took about 40 minutes including the 


\section{Al Macrothink}

Journal of Studies in Education

ISSN 2162-6952

2013, Vol. 3, No. 2

instructor's explanation. At first, the Persian version of TTCT was administered to determine the creativity level of the medical students. Then, the VLS questionnaire, in English, was given to identify the students' use of VLS. The participants were asked to mention their gender, not their names. They were informed that their answers would not affect their marks. The collected data were analyzed using the Statistical Package for Social Science (SPSS), version 14.

\section{Results and Discussion}

\subsection{The participants' Creativity Level}

To measure the creativity level of the students, the Persian version of TTCT which is a valid creativity test was administered. The results are shown in Table 1.

Table 1. Descriptive statistics of TTCT

\begin{tabular}{|r|r|r|r|r|}
\hline Mean & Std. deviation & Min & Max & N \\
\hline 141.21 & 13.74 & 94 & 170 & 101 \\
\hline
\end{tabular}

As illustrated in Table 1, the minimum and the maximum scores of creativity were 94 and 170, respectively, out of 180. According to the TTCT scoring system, creativity scores of 70 or below 70 show the low level of creativity, scores between 76 and 86 represent the medium level of creativity, and scores above 86 indicate the high level of creativity. Since the range of the participants' scores was 94-170, they all had a high level of creativity.

To answer the second research question, the mean scores of TTCT for male and female students were compared to determine if there was any significant difference in creativity between the two genders. The result is displayed in Table 2, indicating that the difference is not statistically significant in this regard (p. value $>0.05$ ).

Table 2. Comparative descriptive statistics of TTCT based on gender

\begin{tabular}{|r|r|r|r|r|}
\hline Sex & Mean & Std. deviation & $\mathrm{N}$ & Sig. \\
\hline Male & 141.19 & 13.05 & 53 & \multirow{2}{*}{$>0.05$} \\
\hline Female & 141.23 & 14.61 & 48 & \\
\hline Total & 141.21 & 13.74 & 101 & \\
\hline
\end{tabular}




\section{Macrothink}

\subsection{Creativity and VLS Use}

The third research question, which was the main question of this study, sought to answer if there is a relationship between creativity and VLS use. Pearson correlation was run between creativity and different categories of VLS to search for the possibility of any significant correlation. The findings are presented in Table 3.

Table 3. Rank order of the Pearson Correlation Coefficient between creativity and VLS

\begin{tabular}{|l|r|r|r|r|r|r|r|r|r|}
\hline & Autonomy & Social & Guessing & Memory & $\begin{array}{r}\text { Study } \\
\text { Preferences }\end{array}$ & Dictionary & $\begin{array}{r}\text { Note } \\
\text { taking }\end{array}$ & $\begin{array}{r}\text { Selective } \\
\text { Attention }\end{array}$ & $\begin{array}{r}\text { Overall } \\
\text { VLS Use }\end{array}$ \\
\hline Creativity & $0.34 * *$ & $0.33 * *$ & $0.23 *$ & $0.22 *$ & 0.002 & 0.13 & -0.02 & 0.14 & $0.29 * *$ \\
\hline
\end{tabular}

* Significant at the 0.05 Level (2 tailed)

* * Significant at the 0.01 Level (2 tailed)

As it is evident from Table 3, half of the strategies, 4 out of 8, had significant correlations with creativity. Autonomy (0.34), social (0.33), guessing (0.23), and memory strategies $(0.22)$ were correlated with creativity. Therefore, the more creativity, the more use of these strategies was observed. In other words, our highly creative students were autonomous learners who made chances to learn and use English outside the class. They made significant use of social strategies, i.e. interaction with other people whether natives or non-natives. The more creative learners also remarkably employed guessing and memory strategies. In general, a significant correlation (0.29) was found between creativity the overall VLS use of Iranian medical students at the 0.05 significance level.

To answer the last research question and see whether there was any significant difference in the relationship between creativity and the overall VLS use according to gender, Pearson correlation was separately applied for males and females. Table 4 shows the results for males. 


\section{IIMacrothink}

Journal of Studies in Education

ISSN 2162-6952

2013, Vol. 3, No. 2

Table 4. Rank order of the Pearson Correlation Coefficient between creativity and VLS in Males

\begin{tabular}{|l|r|r|r|r|r|r|r|r|r|}
\hline & Social & Autonomy & Guessing & Memory & $\begin{array}{r}\text { Study } \\
\text { Preferences }\end{array}$ & Dictionary & $\begin{array}{r}\text { Note- } \\
\text { taking }\end{array}$ & $\begin{array}{r}\text { Selective } \\
\text { Attention }\end{array}$ & $\begin{array}{r}\text { Overall } \\
\text { VLS Use }\end{array}$ \\
\hline Creativity & 0.35* & $0.34 *$ & 0.10 & 0.08 & 0.09 & 0.09 & -0.10 & 0.16 & 0.21 \\
\hline
\end{tabular}

* Significant at the 0.05 Level (2 tailed)

Although significant correlations were found between creativity and social and autonomy strategies, no significant correlation was observed between creativity and the overall VLS use in males.

For females, the rank order of the Pearson correlation coefficient between creativity and VLS is presented in Table 5.

Table 5. Rank order of the Pearson Correlation Coefficient between creativity and VLS in Females

\begin{tabular}{|r|r|r|r|r|r|r|r|r|r|}
\hline & Memory & Autonomy & Social & Guessing & $\begin{array}{r}\text { Study } \\
\text { Preferences }\end{array}$ & Dictionary & $\begin{array}{r}\text { Note } \\
\text { taking }\end{array}$ & $\begin{array}{r}\text { Selective } \\
\text { Attention }\end{array}$ & $\begin{array}{r}\text { Overall } \\
\text { VLS } \\
\text { Use }\end{array}$ \\
\hline Creativity & $0.39 * *$ & $0.35 *$ & $0.33 *$ & $0.33 *$ & -0.09 & 0.16 & 0.08 & 0.11 & $0.37 *$ \\
\hline
\end{tabular}

* Significant at the 0.05 Level (2 tailed)

** Significant at the 0.01 Level (2 tailed)

The strongest correlation was observed between creativity and memory strategy (0.39). Significant correlations were also found between creativity and autonomy, social and guessing strategies. Unlike males, the correlation between creativity and the overall VLS use was statistically significant in females (0.37).

\section{Conclusion and Pedagogical Implications}

The findings of this study revealed that this group of Iranian EFL learners, medical students 
at SUMS, all had a high level of creativity. No statistically significant difference was observed between males' and females' creativity. Regarding the relationship between creativity and VLS use, the results indicated significant correlations between creativity and four (out of eight) VLSs, i.e. autonomy, social, guessing, and memory strategies. The highest (0.34) and lowest $(0.22)$ correlations belonged to autonomy and memory strategies, respectively. Also, the correlation between creativity and overall VLS use (0.29) of the participants was statistically significant at the 0.05 level. Therefore, it can be concluded that there is a significant relationship between creativity and VLS use in general. As to gender, while no significant correlation was found between creativity and the overall VLS use of males, for females this correlation was statistically significant. Therefore, it can be concluded that sex variable has played a mediator role and influenced the relationship between creativity and VLS use in a general.

The strong link found between creativity and VLS use persuades English teachers, curriculum designers and even parents to consider creativity as an effective factor in successful second /foreign language learning in general and in vocabulary learning in specific. So, flourishing creativity may enhance the use of VLS, leading to successful language acquisition.

\section{Limitations of the Study}

In order to obtain generalizable conclusion, a large scale research is recommended. In our study all the participants were in a high level of creativity and their performance was very similar. The same study can be conducted at other medical schools on subjects with different backgrounds and perhaps different levels of creativity to further confirm our results.

\section{References}

Abutalebi, J., \& Cosat $<$ A. (2008). Editoal, acquisition, processing and loss of L2: Functional, cognitive and Neural perspectives. Journal of Neurolinguistics, 21, 473-476. http://dx.doi.org/10.1016/j.jneuroling.2008.10.001

Akbari, Z., \& Tahririan, M.H. (2009). Vocabulary learning Strategies in an ESP context: The case of Para/medical English in Iran. The Asian EFL Journal Quarterly, 11(1), 36-61.

Albert, A. (2006). Learner's creativity as a potentially important variable: Examine the relationships between learner creativity, language aptitude and level of proficiency. In $\mathrm{M}$. Nikolove, \& J. Horvath (Eds.). Empirical studies in English Applied Linguistics, 77-989. Hungary, Eotous University.

Albert, A., \& Kormos, J. (2011). Creativity and narrative task performance: An exploratory study. Language Leaning, 61(1), 73-99. http://dx.doi.org/10.1111/j.1467-9922.2011.00643.x

Altman, H. (1980).Foreign language teaching: Focus on the learner. In H. Altman, \& J. Vaughan (Eds.), Foreign Language Teaching: Meeting Individual Needs, 1-16. Oxford, UK: Pergamon.

Catalan, R.M.J. (2003). Sex differences in L2 Vocabulary Learning strategies. International 
Journal of Applied Linguistics, 13(1), 54-77. http://dx.doi.org/10.1111/1473-4192.00037

Cohen A., \& Dornyei, Z. (2002). Focus on the language learners: Motivation, styles, and strategies. In N. Schmitt (Ed.), An Introduction to Applied Linguistics, 35-54. Oxford: Oxford University Press.

Dörnyei, Z. (2005). Motivational strategies in the Language Classroom. Cambridge: Cambridge University press.

Ellis, R. (1994). The Study of Second Language Acquisition. Oxford: Oxford University press.

Fahim, M,. \& Komijani, A. (2010). Critical thinking ability. L2 vocabulary knowledge and L2 vocabulary learning strategies. Journal of English Studies, IAUSRB, 1(1), 23-38.

Fan, Y.M. (2003). Frequency of use, perceived usefulness, and actual usefulness of second language vocabulary strategies: A study of Hong Kong learners. The Modern Language Journal, 87(2), 222-241. http://dx.doi.org/10.1111/1540-4781.00187

Gu,Y. \& Johnson, R.K. (1996). Vocabulary learning strategies and language learning outcomes. Language Learning. 46(6), 643-676. http://dx.doi.org/10.1111/j.1467-1770.1996.tb01355.x

Hadley, A.O. (2003). Teaching Language in Context. (3rd ed.). Massachusetts: Heinle \& Heinle Publishers.

Hajilou, Y., Yazdani, H., \& Shokrpourn, N.. (2012). The relationship between Iranian EFL learners' creativity and their lexical reception and production knowledge. English Language Teaching, 5(3), 131-146.

Heidari, F., Izadi, M., \& Vahedahmadian, M.. (2012). The relationship between Iranian EFL learners' self efficacy beliefs and use of vocabulary learning strategies, English Language Teaching, 5(2), 174-179. http://dx.doi.org/10.5539/elt.v5n2p174

Jones, R. (2006). Vocabulary learning strategy use among tertiary students in the United Arab Emirates. Perspective, 14(1), 4-8.

Kafipour, R., Yazdani, M., Soori, A., \& Shokrpour, N. (2011). Vocabulary levels and vocabulary learning strategies of Iranian undergraduate students. Studies in Literature and Language, 3(3), 64-71.

Kim, H.K. (2008). Commentary: The Torrance tests of creative thinking already overcome many of the perceived weaknesses that Silvia et al.'s (2008) methods are intended to correct. Psychology of Aesthetics, Creativity and the Arts, 2(2), 97-99. http://dx.doi.org/10.1037/1931-3896.2.2.97

Larsen-Freeman, D., \& Long, M. (1991). An introduction to Second Language Acquisition. London: Longman.

Matsouka, O., Trevalse, E., Zachopoulou, E. (2003). Relationship between playfulness and 
motor creativity in preschool children. Early Childhood Development and Care, 173(5), 535-543. http://dx.doi.org/10.1080/0300443032000070482

Nation, I.S.P. (1990). Teaching and Learning Vocabulary. New York: Newbury.

Nation, I.S.P. (2001). Learning Vocabulary in Another Language. Cambridge: Cambridge University press. http://dx.doi.org/10.1017/CBO9781139524759

Naveh, M.H., Kafipour, R., \& Soltani, R. (2011). The relationship among extroversion tendency, vocabulary learning strategies and reading comprehension of EFL undergraduates in Kerman Province. Studies in Literature and Language, 3(2), 104-110.

O’ Malley, J. \& Chamot, A. (1990). Learning Strategies in Second language Acquisition. Cambridge: Cambridge university press. http://dx.doi.org/10.1017/CBO9781139524490

Otto, I. (1998). The relationship between individual differences in learner creativity and language learning success. TESOL Quarterly, 32, 763-773. http://dx.doi.org/10.2307/358801

Oxford, R. L. (1990). Language Learning Strategies: What Every Teacher Should Know. Boston: Newbury House.

Oxford, R. (1995).Gender differences in language learning styles: What do you mean? In J. Reid (Ed.), Learning Styles in the ESL/EFL Classrooms, 3-18. Boston: Helinle \& Helinle.

Riazi, A., Seddighi, F., \& Zare, S.A. (2005). The effect of EFL students' L2 proficiency and age on their overall pattern of vocabulary learning strategy use. Iranian Journal of Applied Linguistics, 8(2). 87-106.

Rubin, J. (1987). Learner strategies: Theoretical assumption, research history and typology. In A. Wenden, \&J. Rubin (Eds.), Learners Strategies in Language Learning, (15-29). New York: Prentice Hall.

Schmitt, N. (1997). Vocabulary learning strategies. In N. Schmitt \& M. Mc Carthy (Eds.), Vocabulary:Description, Acquisition and Pedagogy. (199-227). Cambridge University Press.

Schmitt, N. (2000). Vocabulary in Language Teaching. Cambridge: Cambridge University Press.

Seddigh, F \& Shokrpour, N. (2012). Vocabulary learning strategies of medical students at Shiraz University of Medical Sciences. English Language Teaching, 5(2), 160-173. http://dx.doi.org/10.5539/elt.v5n2p160

Segalowitz, N. (1997). Individual differences in second language acquisition. In A. de Groot, \& J. Kroll (Eds.), Tutorials in Bilingualism, 85-112. Hillsdale, NJ: Lawrence Erlbaum Associates.

Skehan, P. (1989). Individual Differences in Second Language Learning. London: Edward Arnold.

Soodmand Afshar, H. (2010). Iranian EFL learners' most and least frequently used vocabulary learning strategies: The relation to success and gender. The Iranian EFL Journal, 
6(1), 72-100.

Sternberg, R.J. (1985). Implicit theories of intelligence, creativity, and wisdom. Journal of $\begin{array}{llll}\text { personality and social } \quad \text { and } & \text { 607-627. }\end{array}$ http://dx.doi.org/10.1037/0022-3514.49.3.607

Torrance, E.P. (1990). The Torrance test of creative thinking norms-technical manual figural (streamlined )forms A \&B. Bensenville. IL: Scholastica Testing Service, Inc.

Yar Hamidi, D., Wennberg, K., \& Berglund, H. (2008). Creativity in entrepreneurship education. Journal of Small Business and Enterprise Development, 15(2). 304-320. http://dx.doi.org/10.1108/14626000810871691 